\title{
Long-term monitoring of coastal ecosystems at Las Cruces, Chile: Defining baselines to build ecological literacy in a world of change
}

\author{
Monitoreo de largo plazo en el ecosistema marino costero de Las Cruces, Chile: Defi- \\ niendo líneas base para construir alfabetización ecológica en un mundo que cambia
}

\section{SERGIO A. NAVARRETE*, STEFAN GELCICH \& JUAN C. CASTILLA}

Estación Costera de Investigaciones Marinas, Center for Advanced Studies in Ecology and Biodiversity, \& Laboratorio Internacional de Cambio Global (LINCGlobal, CSIC-PUC) Pontificia Universidad Católica de Chile, Casilla 114-D,

* Corresponding author: snavarrete@bio.puc.cl

\begin{abstract}
Marine coastal habitats are being increasingly impacted by human activities. In addition, there are dramatic climatic disruptions that could generate important and irreversible shifts in coastal ecosystems. Long-term monitoring plays a fundamental and irreplaceable role to establish general baselines from which we can better address current and future impacts and distinguish between natural and anthropogenic changes and fluctuations. Here we highlight how over 25 years of monitoring the coastal marine ecosystem within the notake marine protected area of Las Cruces has provided critical information to understand ecological baselines and build the necessary ecological literacy for marine management and conservation. We argue that this understanding can only be gained with simultaneous monitoring of reserves and human-impacted areas, and the development of complementary experimental studies that test alternative hypothesis about driving processes and mechanisms. In this contribution we selected four examples to illustrate long-term temporal fluctuations at all trophic levels including taxa from algae to sea birds. From these examples we draw a few general lessons: a) there is co-occurrence of rapid- and slowly- unfolding ecological responses to the exclusion of humans within the same rocky shore community. The sharp differences in the pace at which depleted populations recover is at least partly related to differences in life history (dispersal capabilities) of the targeted species. b) Long-term monitoring of the supply-side of marine communities is critical to evaluate the potential feedback effects of local changes in abundance into the arrival of new individuals and to correctly evaluate environmental and human-induced perturbations. c) Unexpected changes in local population dynamics can occur in "independent" and apparently non-interactive modules of the marine ecosystem, such as roosting sea birds inside the reserve. In addition we discuss the way in which ecological data generated from long-term monitoring at marine reserves was institutionalized in a national marine management policy. At the same time, we highlight the mismatch between the gained scientific information and principles from these studies and the current concept of marine protected areas that is being implemented by some government agencies in Chile. Information from long term monitoring programs has proved essential to understand how marine environments respond to anthropogenic and/or natural disturbances, however funding these schemes, which generally have no short term gains for funding agencies in both developing and developed countries, still remain a major challenge.
\end{abstract}

Key words: community structure, conservation, keystone species, marine reserves, policy.

\section{RESUMEN}

Los ambientes marinos costeros están siendo impactados en forma creciente por las actividades humanas. Además, perturbaciones asociadas a cambios climáticos pueden producir cambios dramáticos e irreversibles en estos ecosistemas. El monitoreo de largo plazo juega un rol fundamental e irremplazable para establecer líneas-base sobre las cuales podemos establecer impactos actuales y futuros y distinguir entre cambios antropogénicos y fluctuaciones naturales. En este estudio resaltamos cómo el monitoreo de más de 25 años en la reserva marina costera no extractiva de Las Cruces ha entregado información crítica sobre líneas-bases ecológicas y ha ayudado a comprender ecosistemas costeros para su manejo y conservación. Planteamos que este conocimiento solo puede ser adquirido a través del monitoreo simultáneo en zonas de reservas y en zonas impactadas por el humano (de libre acceso), en conjunto con estudios experimentales complementarios para poner a prueba hipótesis acerca de los procesos y mecanismos que subyacen a los patrones observados. En este artículo seleccionamos cuatro ejemplos para ilustrar patrones temporales de 
largo plazo en todos los niveles tróficos, incluyendo taxa que van desde las macroalgas a las aves marinas. De estas experiencias surgen algunas lecciones generales: a) existe una coocurrencia de respuestas ecológicas rápidas y lentas frente a la exclusión de humanos en la misma comunidad costera rocosa. Las marcadas diferencias entre las tasas de recuperación de poblaciones afectadas son al menos en parte dependientes de las historias de vida (capacidad de dispersión) de estas. b) El monitoreo de largo plazo del "abastecimiento" de nuevos individuos (reclutamiento) en comunidades marinas es crítico para evaluar la potencial retroalimentación de cambios en abundancia local sobre la llegada de nuevos individuos y de esta forma evaluar correctamente perturbaciones ambientales o antrópicas. c) Cambios inesperados en dinámicas poblacionales pueden ocurrir en módulos aparentemente independientes del ecosistema litoral, como lo son las aves marinas que descansan o anidan al interior de la reserva. Adicionalmente, discutimos la forma en la cual datos ecológicos generados a partir de monitoreos de largo plazo fueron institucionalizados en un artículo de la ley de pesca y acuicultura. Al mismo tiempo resaltamos el desfase entre el conocimiento adquirido de los estudios de largo plazo en reservas marinas e instrumentos de conservación marina implementados por algunas agencias de gobierno en Chile. Concluimos señalando que la información proveniente de monitoreos de largo plazo ha resultado esencial para comprender cómo los ambientes marinos responden a disturbios naturales o antropogénicos, sin embargo el financiamiento de estos programas, que generalmente no tienen grandes ganancias en el corto plazo para las agencias de financiamiento, continúa siendo un gran desafío tanto en países desarrollados como los en vías de desarrollo.

Palabras clave: conservación, especies clave, estructura comunitaria, legislación, reservas marinas.

\section{INTRODUCTION}

One of the important scientific questions today is not whether marine coastal ecosystems have been profoundly transformed by humans over the past hundreds of years, but whether we can understand how they have changed, what components and features have experienced irreversible changes, and how we use scientific knowledge to go from here and minimize past and future losses.

The notion of a bountiful ocean with endless buffer capacity that many of us learned of in high school is long gone. Today, policy makers and resource managers are forced to set targets for conservation and management exercising the "short-term memory" approach, which in a world of slowly but ever sliding baselines (Pauly 1995, Dayton et al. 1998, Jackson et al. 2001, Myers \& Worm 2003) makes us feel more optimistic about the state of coastal ecosystems and the success of conservation and management practices. This is an admittedly bleak scenario; one that some marine ecologists might not agree with. Yet, we argue that if we are to provide useful ecological information about conservation, management and biotic responses to climatic disruptions, it is better to face the fact that marine ecosystems, from the intertidal zone down to the abyssal ocean, are likely very different to the ones before Homo sapiens (L.) developed the first tools and used the coastal ocean for subsistence. This realization poses monumental challenges when we try to identify the benchmarks against which natural and anthropogenic changes must be discerned and quantified (Dayton et al. 1998). In this thorny and often polemic endeavor (e.g. Worm et al. 2006, Jaenike 2007, Murawski et al. 2007, Worm et al. 2007), long-term monitoring of ecosystems plays a fundamental and irreplaceable role.

Long-term data on physical or biological ecosystem-state variables of marine coastal habitats along the southeastern Pacific are scarce at best. Beyond the obvious limitations to undertake long-term studies imposed by granting agencies, which typically support 2-4 yr long projects, and the increasingly stringent requirements for short $\mathrm{PhD}$ dissertations (Dye 1998b), it appears that other issues have also played a role in the scarce interest paid by marine ecologists (including Chilean) in generating, compiling, or analyzing long-term data (but see, Bustamante \& Castilla 1987, Duarte et al. 1996, Moreno \& Rubilar 1997, Vásquez et al. 2006, for Chilean examples). We believe that the strong emphasis in experimental manipulations and nullhypothesis testing, particularly among rocky shore ecologists (Moreno 1984, Camus \& Lima 1995, Underwood 2000), has sometimes been viewed as contradictory, rather than critically complementary to quantitative monitoring of biological systems (Castilla 2000, Moreno 2001). Indeed, long-term monitoring in coastal systems is fundamental for several practical reasons, but one of them is to assess the accuracy and limitations of our ecological 
models, most of which are based on long-term near-equilibrium expectations, but are typically evaluated against short-term 'snapshop' data. The often, longer-term dynamics of species and species interactions that are fundamental to ecosystem structuring and functioning simply cannot be detected or assessed with such short-term studies. Yet, development of complementary, well designed and replicated experiments are essential to test alternative hypothesis about the driving processes and mechanisms underplaying the temporal changes. As longer term data becomes available, these hypotheses will likely need to be reformulated and evaluated through new experiments. As stated above, long-term data is our only hope to establish meaningful, though imperfect benchmarks against which the current ecosystem-state of the coastal ocean can be compared and targets for management and conservation could be set. Here, the establishment and monitoring of Marine Protected Areas (MPA), when compared with long-term information on exploited (open-access) shores, gives us an opportunity to discern natural change in environmental variables from direct impacts caused by human exploitation (Castilla 1999, Carr 2000, Castilla 2000, Castilla et al. 2007a, Barrett et al. 2009). Finally, long-term biological information and simultaneous environmental data represent the only way to correctly identify transient behavior from longer-term trends and cycles (Dye 1998a), and to uncouple internal system dynamics from climate-driven fluctuations (Stenseth et al. 2002, Stenseth et al. 2003).

In this contribution, we use examples from the no-take MPA reserve site of the Estación Costera de Investigaciones Marinas (ECIM) at Las Cruces to illustrate the importance of longterm observations in the coastal ocean and highlight the need to create, maintain and monitor no-take marine protected areas in the coast of Chile. Since we cannot attempt to summarize here the wealth of ecological information generated at Las Cruces since its creation in 1982, we selected four examples of temporal fluctuations that include all trophic levels, including taxa from algae to sea birds. For the sake of space, we only sparsely cite the experimental work that support our interpretation of the changes observed in the reserve, but the importance of this work could not be over-stated. We discuss how knowledge generated from this long-term monitoring program was institutionalized in marine management and conservation policies. Information from long-term monitoring programs has proved essential to build ecological literacy on how marine environments respond to anthropogenic and/ or natural disturbances and how these could be managed. However, financing these schemes which generally have no short term gains for funding agencies in both developing and developed countries still remains a major challenge.

\section{Las Cruces Marine Protected Area: 25 years of monitoring a no-take reserve in Chile}

The no-take marine reserve of ECIM is a stretch of about $500 \mathrm{~m}$ of wave-exposed rocky shore and 10 hectares of subtidal rocky reefs that was closed to fishers and tourists in October 1982. The main changes that ensued in the rocky shore communities after the exclusion of humans have been amply reported (Castilla \& Durán 1985, Oliva \& Castilla 1986, Durán \& Castilla 1989, Castilla 1993, Botsford et al. 1997, Castilla 1999, Cornelius et al. 2001, Loot et al. 2005), and have some similarities with those that occurred at another, University-owned marine protected area in Mehuín, near Valdivia in southern Chile (Jara \& Moreno 1984, Moreno et al. 1984, Godoy \& Moreno 1989). Moreno (2001) provides a review of the main ecological changes observed in the Mehuin reserve, with several examples of unprecedented and unanticipated changes that were documented only because of the existence of historical records. Unfortunately, the marine reserve of Mehuín was terminated in 1991 (Fernandez \& Castilla 2005). This means that the protected area of Las Cruces is the only existing and effective marine reserve in Chile for which there is ecological information and long-term monitoring.

The rapid and long-lasting effects of local processes

One of the clearest changes that took place inside the ECIM reserve after the exclusion of humans was the increase in density and overall 
biomass of the muricid gastropod Concholepas concholepas (Brugiére) ("loco"), a highly prized species that is intensively collected by fishers in open access areas and a top carnivore that feeds preferentially on intertidal mussels (Castilla \& Durán 1985, Castilla \& Paine 1987, Durán \& Castilla 1989). The 4-5 times higher density of Concholepas inside the reserve of ECIM compared to areas immediately outside (Fig. 1) led to the rapid intertidal decline of what were extensive beds (monocultures) of the competitively dominant mussel Perumytilus purpuratus (Lamarck), which released bare rock surface for colonization and establishment of other sessile species, particularly two species of chthamalid barnacles, Jehlius cirratus (Darwin) and Notochthamalus scabrosus (Darwin), which quickly settle and covered most of the freed rock surface (Fig. 2). The majority of these changes occurred swiftly after closure to humans and with comparatively short delays throughout the coastline protected by the reserve. By late 1985, the seascape in the mid intertidal zone inside the reserve was dramatically different to the one outside. There, where fishers continually removed what turned out to be a keystone predator (Power et al. 1996, Navarrete \& Castilla 2003), mussels continued to dominate the mid intertidal zone and barnacles and other sessile species (not shown here) remained restricted to sparse patches within the mussel bed monoculture (Fig 2). Details of this story of cascading interactions and indirect effects affecting all trophic levels of the intertidal community have been presented in several publications (Castilla \& Durán 1985, Oliva \& Castilla 1986, Durán \& Castilla 1989, Bustamante \& Castilla 1990, Castilla 1999).

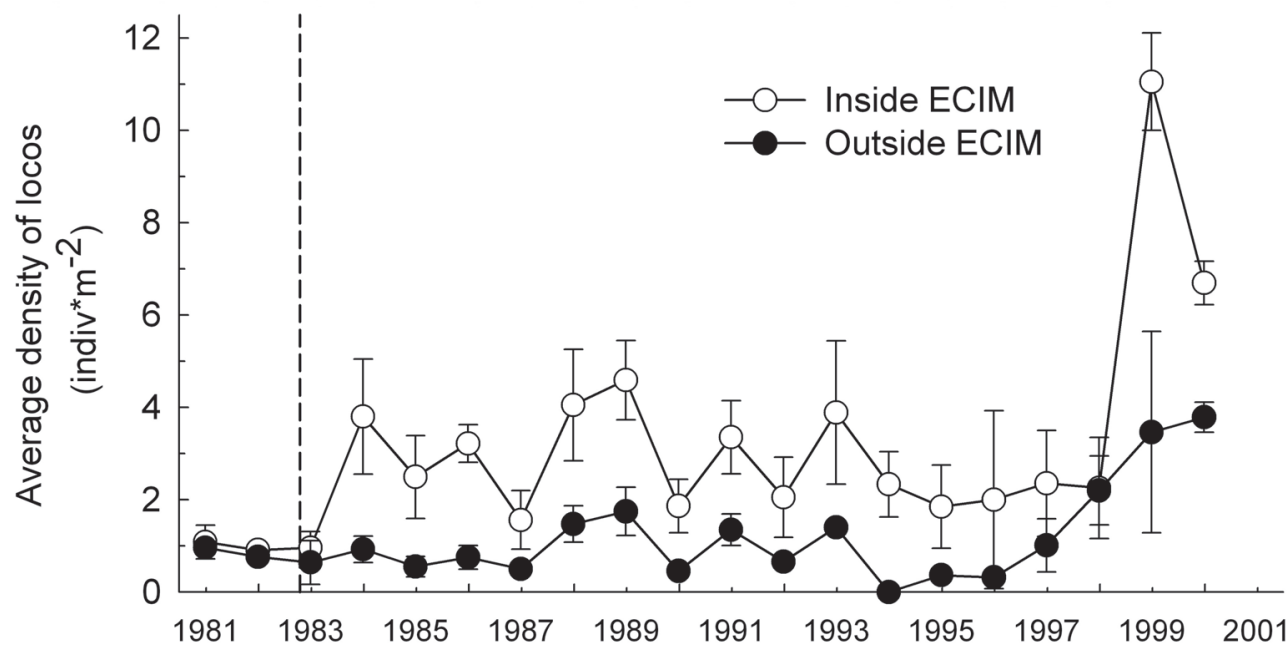

Fig. 1: Abundance of the intertidal carnivore gastropod Concholepas concholepas in spring-summer months between 1981 and 2000 at 7-10 sites inside the ECIM marine reserve and in adjacent, 'open access' areas to the south (outside ECIM). Data correspond to mean density ( \pm SE) of individuals (juveniles and adults pooled together) in $1 \mathrm{~m}^{2}$ quadrats haphazardly distributed at 7-10 wave exposed sites amongst and immediately above the holdfasts of the kelp Lessonia nigrescens in the low intertidal zone. Vertical dashed line indicates the time the marine reserve was established and humans were excluded. Details of methods can be found in Castilla \& Durán (1985) and Durán \& Castilla (1989).

Abundancia del gastrópodo intermareal carnívoro Concholepas concholepas en meses de primavera-verano entre 1981 y 2000 en 7-10 sitios al interior de la reserva marina de ECIM y en zonas adyacentes de "acceso abierto" al sur (afuera de ECIM). Los datos corresponden a densidad ( \pm EE) de individuos (juveniles y adultos juntos) en cuadrantes de $1 \mathrm{~m}^{2}$ dispuestos azarosamente en 7-10 sitios expuestos al oleaje entre los discos e inmediatamente por sobre el alga Lessonia nigrescens en la zona intermareal baja. La línea segmentada vertical indica el momento en que la reserva fue establecida y los seres humanos se excluyeron. Detalles de los métodos se pueden encontrar en Castilla \& Durán (1985) y Durán \& Castilla (1989). 


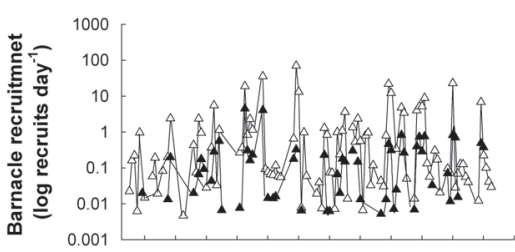

- Mussels Outside

- Barnacles Outside

- - Mussels Inside

$\triangle$ Barnacles Inside
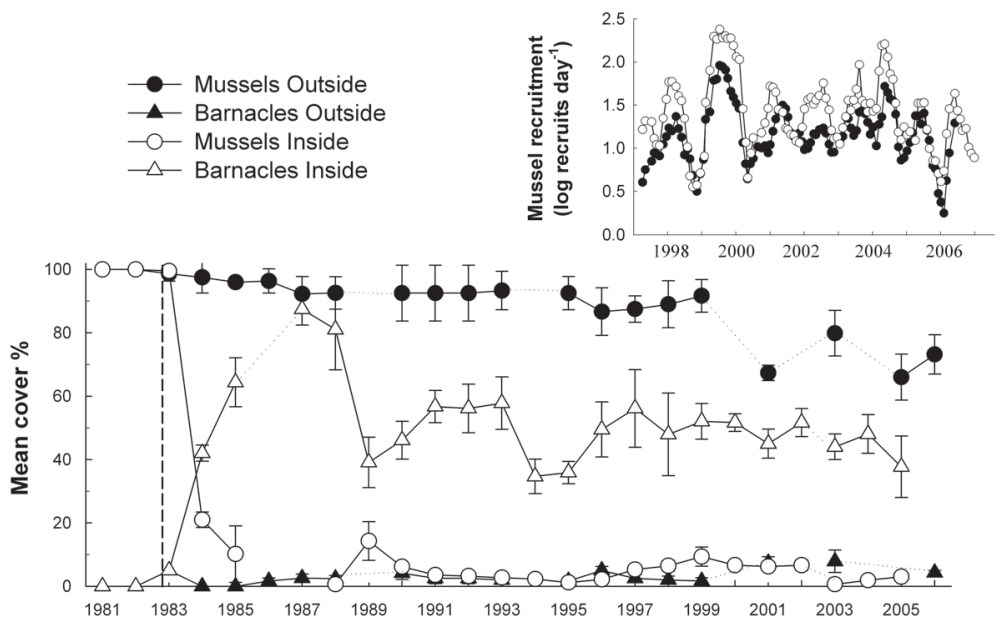

Fig. 2: Average cover $(\% \pm \mathrm{SE})$ of the mussel Perumytilus pupuratus and chthamalid barnacles (Jehlius cirratus and Notochthamalus scabrosus pooled together) in spring-summer months at the intertidal zone of the ECIM marine reserve (inside) and in the 'open access' shore to the south (outside). Between 1981 and 2000 cover was estimated using 4-8 $1 \mathrm{~m}^{2}$ quadrats (81 intersection points), haphazardly positioned on gently sloping $\left(<45^{\circ}\right)$ wave exposed platforms. After year 2000 cover was estimated with $10-120.25 \mathrm{~m}^{2}$ quadrats haphazardly positioned in the same platforms. Vertical dashed line indicates the time the marine reserve was established and humans were excluded. The dotted connecting lines indicates years when data were not collected in spring-summer months and were not included for consistency. Details of methods can be found in Castilla \& Durán (1985) and Castilla et al. (1993). The two inserts show monthly recruitment rates of barnacles (top panel) and mussels (mid panel) at high and mid intertidal platforms, respectively, at sites inside and outside the ECIM marine reserve between 1997 and 2007. Recruitment data are expressed here as the logarithm of the number of individuals found per artificial collector ( 5 plates for barnacles, 5 Tuffy scrubbing pads for mussels) per day, by dividing by the number of days collectors were in the field (usually 25-45 days). Data for barnacle includes only spring-summer months since no recruitment occurs in winter time. Data for mussels include all months of the year and presented here as 3month moving averages. Details of recruitment methods and data treatment can be found in Navarrete et al. (2002), Navarrete et al. (2005) and Navarrete et al. (2008).

Cobertura promedio $(\% \pm$ EE) del mitílido Perumytilus purpuratus y cirripedios chthamalidos (Jehlius cirratus y Notochthamalus scabrosus agrupados) en meses de primavera- verano en la zona intermareal al interior de la reserva de ECIM (inside) y en zonas de acceso abierto (outside) al sur. Entre 1981 y 2000 la cobertura se estimó mediante 4-8 cuadrantes ( 81 puntos de intersección) dispuestos azarosamente en plataformas expuestas al oleaje y de baja inclinación $\left(<45^{\circ}\right)$. Después del año 2000 la cobertura se estimó mediante $10-12$ cuadrantes de $0.25 \mathrm{~m}^{2}$ posicionados azarosamente en las mismas plataformas. La línea vertical segmentada indica el momento en que se estableció la reserva marina y los seres humanos fueron excluidos. La línea punteada conectando las observaciones indica los años en que no se recolectaron datos en primavera-verano y no fueron incluidos para mantener la consistencia. Detalles de los métodos pueden ser encontrados en Castilla \& Durán (1985) y Castilla et al. (1993). Los dos gráficos insertos muestran la tasa de reclutamiento de cirripedios (arriba) y mitílidos (central) en la zona intermareal alta y media, respectivamente, en sitios al interior y afuera de de la reserva marina de ECIM entre 1997 y 2007. Los datos de reclutamiento son expresados en logaritmo del número de individuos observados por colector artificial (5 placas para cirripedios, 5 Tuffy para mitílidos) por día, a través de dividir por el número de días que los colectores estuvieron en terreno (usualmente 25-45 días). Los datos de cirripedios incluyen solamente primavera-verano pues no ocurre reclutamiento en invierno. Los datos de mitílidos incluyen todos los meses del año y se presentan aquí como promedios móviles de una ventana de 3 meses. Detalles de métodos para cuantificar reclutamiento se encuentran en Navarrete et al. (2002), Navarrete et al. (2005) y Navarrete et al. (2008). 
Continued monitoring of the coastal ecosystem of Las Cruces for the past 25 years showed a remarkable persistence of this modified, some might say 'natural' state inside the reserve. First, the abundance (cover) of barnacles within the reserve declined from a maximum of about $80 \%$ to around $50-60 \%$ by 1989 (Fig. 2), partly as a response to competition with macroalgae and partly due to intensified predation on barnacles by locos and other predators once mussels were harder to find (Durán \& Castilla 1989, Castilla 1999). After 1989 barnacle cover has fluctuated, without a clear cycle or periodicity, at around this $50-60 \%$ for the past 18 years and there are no signs of declines (Fig. 2). After the near elimination of mussel beds inside the reserve, dropping from complete dominance to less than $10 \%$ by 1984 , mussels have never recovered in these 23 years, despite considerable fluctuations in the abundance of Concholepas inside the reserve (Fig. 1) and the persistence of high mussel cover immediately outside (Fig. 2). After year 2000 there was a small decline in mussel bed cover outside the reserve (Fig. 2), but this change could be due in part to slight changes in the protocol followed to quantify mussel cover (from fixed points to random quadrants).

The stunning persistence of the seascape inside the reserve begs the question of whether this ca. $500 \mathrm{~m}$ of coastline represents well the ecosystem state before humans started to extract Concholepas and many other invertebrates and algae, i.e. whether the marine reserve is a "baseline" of what a natural system looked like. This we can not know for certain, largely because of the limited and single spatial scale provided by the ECIM reserve. Glimpses into the past obtained by studying shell middens of preColumbian subsistence gatherers suggest that large bodied gastropod and limpets were common (Jerardino et al. 1992), but it is hard to re-construct patterns of abundance of nonedible species, such as small mussel and barnacles.

A different explanation for the persistent seascape inside the reserve is that the rapid response by the keystone predator pushed the system into an alternative, possibly stable state (sensu Lewontin 1969), different to the one found in pre-historic times (e.g., Scheffer et al.
2001). This would mean that even if Concholepas and other invertebrates were reduced to levels observed outside, the current state of system inside the reserve would persist through local feedback mechanisms. For instance, considering the spatial extent and dramatic changes in overall mussel and barnacle population sizes inside the reserve, is it possible that these changes have affected the rates of arrival of new individuals? If low mussel abundance leads to low mussel recruitment and high barnacle abundance leads to increased recruitment rates, then the reserve ecosystem would have some critical feedback mechanisms. Considering that mussels and barnacles have free swimming pelagic larvae that develop in the plankton for a few weeks (Thorson 1950, Roughgarden et al. 1988), it is difficult to imagine that changes at the scale of the reserve affect recruitment rates, yet this proposition should be evaluated through additional observations and experiments.

\section{Mussel and barnacle recruitment: The supply side of marine communities}

In 1997 we began monitoring monthly recruitment of mussels, barnacles and several other invertebrate species at sites inside the ECIM reserve, outside the reserve and 14 other localities along the coast of central Chile (Navarrete et al. 2002, Navarrete et al. 2005). The use of the same, replicated artificial collectors, which are replaced monthly at all sites and examined under the microscope (see Martínez \& Navarrete 2002, Navarrete et al. 2002, Navarrete et al. 2008, for details) permits an estimation of the rate of arrival of new individuals at a given site. Results illustrate several issues.

First, while mussel abundance declined rapidly and remained at low levels for 23 years following the increase in Concholepas, mussel recruitment rates to this shore have been as high or higher than recruitment to nearby open-access areas, at least over the past 10 years (Fig. 2 inserts). This reinforces the importance of humans as top predators (Castilla 1993) that can control the importance of key local processes (predation), which can then cascade down to mussels and the general structure of the entire local community, even 
when there is abundant mussel larvae to recover the prey population.

Second, long-term recruitment data clearly show that the near elimination of mussel beds from the ca. $500 \mathrm{~m}$ coastline inside the marine reserve, has had no negative effects on the availability of larvae in the water column and potential recruitment of young. Similarly, increased abundance of barnacles does not appear to have produced increased barnacle recruitment inside the reserve as compared to nearby areas (Fig. 2 insert). This clearly indicates that the dispersal scales of mussel and barnacle larvae are way beyond the scales of this marine reserve and adjacent habitats. This is probably an obvious result for many marine ecologists. Nonetheless it is one of tremendous relevance when assessing the separate and combined effects of marine reserve size, rates of larval replenishment and internal species interactions (e.g., predator- prey interactions) including demographic feedbacks, on the structure and dynamics of ecosystems (Carr \& Reed 1993, Botsford et al. 2001, Shanks et al. 2003, Navarrete et al. 2005, Wieters et al. 2008). Thus, we cannot envision any coastal long-term monitoring program without quantitative evaluation of recruitment rates.

The long-term trend in loco following the exclusion of humans

When examining long-term data on Concholepas abundance inside and outside the marine reserve, it is apparent that densities have remained generally higher inside than outside, but also that this gastropod undergoes periodic fluctuations in abundance that are not observed in the abundance of its mussel and barnacle prey on the same shore (Figs. 1 and 2). Lack of local bottom-up effects from prey to predators'

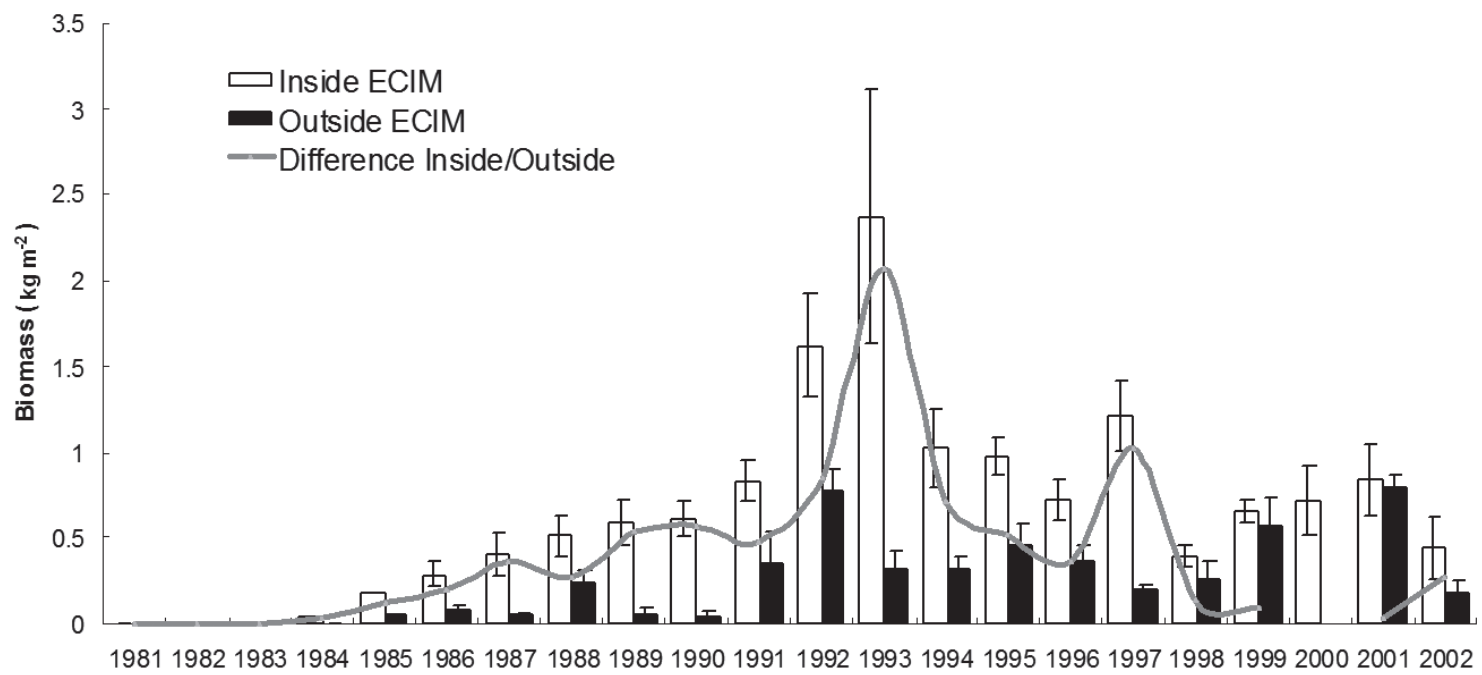

Fig. 3: Average biomass ( \pm SE) of adult Durvillaea antarctica ("cochayuyo") kelp in the low intertidal zone of ECIM (white bars) and in adjacent open access areas to the north (black bars) during spring low tides between 1981 and 2002. Data correspond to the total biomass of adult plants found along $500 \mathrm{~m}$ long transects of variable width conducted inside and outside the ECIM reserve. The gray line represents the differences in biomass between ECIM and the open access areas with spline smoothing to better capture longer-term trends. Details of the methods can be found in (Castilla et al. 2007a).

Promedio de biomasa ( \pm EE) de adultos del alga parda Durvillaea antarctica ("cochayuyo”) en la zona intermareal baja de la ECIM (barras blancas) y de zonas adyacentes de libre acceso hacia el norte (barras negras), durante mareas bajas de primavera entre 1981 y 2002. Los datos corresponden al total de plantas adultas encontradas a lo largo de transectos de $500 \mathrm{~m}$ de largo y ancho variable realizados al intertior y afuera de la reserva marina de ECIM. La línea grís respresenta la diferencia en biomasa entre ECIM y la zona de acceso abierto con un suavizado "spline" para capturar mejor tendencias de largo plazo. Detalles de métodos pueden encontrarse en (Castilla et al. 2007a). 
abundance and dependence of predator populations on their own recruitment rates is an expected result of predator-prey interaction in species with pelagic larvae (Gaines \& Lafferty 1995, Wieters et al. 2008) and this could well be an example of such dynamics. Indeed, there is a highly significant temporal correlation in Concholepas abundance inside and outside the reserve $(r=0.81, P<0.001)$, despite contrasting patterns of prey abundance. But a detailed analysis of Concholepas population fluctuations is beyond the scope of this paper. We only want to highlight here the need to monitor local abundances as well as recruitment of species at different trophic levels if we are to understand long-term fluctuations in coastal communities.

The edible kelp Durvillaea antarctica (Chamisso) "cochayuyo": Slow recovery of a short-distance disperser

The rocky, low-shore kelp Durvillaea antarctica (cochayuyo), a short-distance disperser (Hay 1977, Buschmann 1984, Taylor \& Schiled 2005), is an important edible species used for local human consumption, along the central and southern coast of Chile (Gelcich et al. 2006). When the Las Cruces marine coastal station was closed to human intervention 25 years ago, extraction of "cochayuyo" was intensive along the coast and it was therefore hypothesized that the protection of the initially depleted population would recover via selfreplacement, first inside the no-take area, and then would expand to adjacent non-protected (exploited) areas through seeding effects.

Data on adult biomass of cochayuyo collected over 20 years (1981-2002), both inside the Las Cruces no-take reserve and in adjacent harvested (Fig. 3) areas show that: (a) At the time of the establishment of ECIM (1982), the species had an extremely depleted population of less than $0.05 \mathrm{~kg} \mathrm{~m}^{-2}$, comparable to the abundance observed outside. (b) Adult cochayuyo populations slowly but steadily recovered to ca. $0.5 \mathrm{~kg} \mathrm{~m}^{-2}$ inside the reserve in a period of about 5-7 years. During this same period, cochayuyo biomass remained low (ca. $0.1 \mathrm{~kg} \mathrm{~m}^{-2}$ ) in open access areas. (c) In 1992 and particularly 1993, the population reached the highest biomass per unit area in the no-take reserve (up to $2.5 \mathrm{~kg} \mathrm{~m}^{-2}$ ), and thereafter naturally decreased to intermediate levels (ca. $0.5-1 \mathrm{~kg} \mathrm{~m}^{-2}$ ), probably as a result of intra-specific competition or other density dependent processes (Castilla et al. 2007 a). Abundance of cochayuyo remained at this level for at least 8 years (1995-2002). Importantly, re-colonization processes followed in open access areas outside of the reserve. In fact during the 1995-2002 period, cochayuyo biomass in open access areas reached similar values to those inside. These long-term results suggest cross-boundary "seeding effects" between ECIM reserve and nearby open access grounds, however these results might be confounded by a decrease in cochayuyo harvesting activities from open access areas since 1989 (see Castilla et al. 2007a, for further discussion on this topic).

The cochayuyo example highlights the need for long-term monitoring inside and outside MPAs to detect and correctly interpret the relative population dynamics of sessile species with short distance propagule dispersal. Indeed, long-term data proved critical to document population recoveries that took place over at least 13 years. The contrast with the rapid dynamics of mussels and barnacles described above, which occurred on the very same rocky shore, is particularly enlightening.

Unsuspected effects beyond the marine realm and fishers: Roosting seabirds

The examples selected above illustrate the great contrast in the temporal dynamics of important components of the rocky intertidal community that coexist within the same stretch of coastline. At least in part, these differences must be related to the differences in life histories of the species (modes of development and dispersal capabilities) and the size of the marine reserve. But just a few tens of meters away from the intertidal rocks another strong interaction was slowly unfolding. In November 1997 we began monitoring, twice a day, the number of birds resting on the rocks inside the ECIM reserve. At that time, 15 years after the closure of the reserve, sea gulls (Larus dominicanus Lichtenstein) were slightly more abundant than cormorants (Phalacrocorax olivaceus [Humboldt]) during spring-summer days (Fig. 4). In late 1999 we observed the first sea gulls nesting inside the reserve and ever 
since the numbers of chicks hatching has steadily increased. As the reserve became a nesting site for sea gulls, their numbers dramatically increased and surpassed cormorants by 2001, to stabilize at high levels only after 2006 (Fig. 4). At the same time, the number of cormorants within the same area has steadily declined year after year, apparently because of interference with the aggressive nesting sea gulls. Sea gulls regularly feed on rocky intertidal organisms in open access areas as well as the marine reserve Castilla \& Paine (1987), Navarrete \& Castilla (1990), Wieters et al. 2009) and, therefore, the increase observed in the reserve does not seem to be a consequence of changes that occurred in the intertidal zone (Cornelius et al. 2001). Instead, sea gulls seem to recognize the reserve as a safe nesting site simply because people were prevented from walking along the shore (Cornelius et al. 2001). No data exist from before 1997 and roosting birds are only rarely observed in adjacent areas outside the reserve (and are not counted), so we have no data for comparison. We know that gulls never nested on this shore before, but we can only assume that cormorants were as, or more, abundant than sea gulls before 1999. What other changes in the littoral community can be triggered by this drastic but slow shift in bird abundance and composition of birds inside the reserve? On the coast of Maine, (Ellis et al. 2006) documented changes in soil nutrient composition and the structure of the vegetation following changes in relative abundance of other species of cormorants and sea gulls. These changes might have already taken place within the ECIM reserve but gone undocumented because we do not have monitoring of vegetation in the reserve.

On hypothesis testing as a continuous process guided by long-term monitoring

Undoubtedly one of the most influential conceptual developments originating from experimental manipulations in marine systems was the idea that a single "keystone" species

\section{Roosting Birds in ECIM}

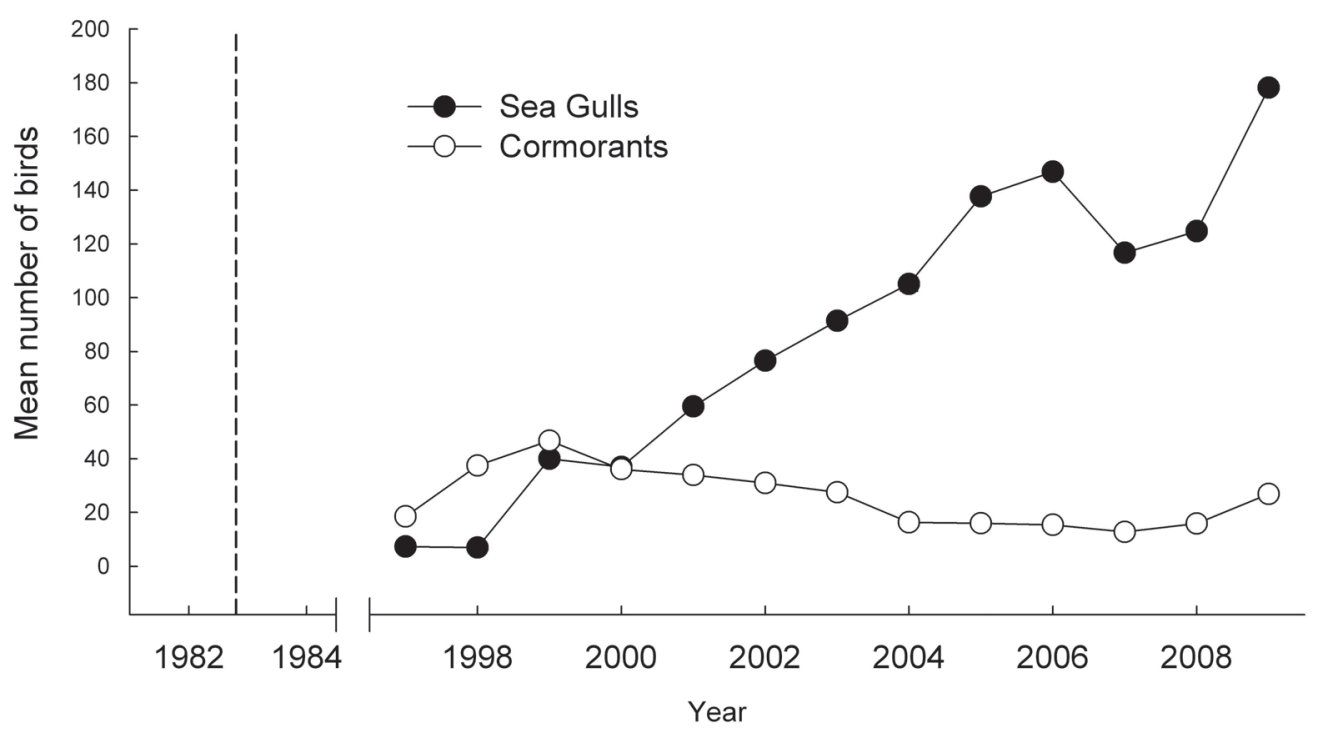

Fig. 4: Mean number ( $\pm \mathrm{SE}$ ) of sea gulls (Larus dominicanus) and common cormorants (Phalacrocorax olivaceus) roosting on rocks in the littoral zone of ECIM reserve during spring-summer months from 1997-2009. Number of birds are counted twice a day at four points inside the reserve throughout the year. Standard errors are based on differences among months.

Número promedio ( \pm EE) de gaviotas (Larus dominicanus) y cormorán común (Phalacrocorax olivaceus) descansando en las rocas de la zona litoral de la reserva de ECIM durante los meses de primavera-verano desde 1997 hasta 2009. Los números de aves son estimados por conteos realizados dos veces al día en cuatro puntos de observación al interior de la reserva a través del año. Errores estándar son basados en diferencias entre meses. 
can be responsible for the maintenance of patterns of community structure, species coexistence and local diversity. The demonstration that the seastar Pisaster ochraceus (Brandt) was a "keystone predator", conducted by (Paine 1966) on the coast of Washington, USA, spurred a series of experiments around the world designed to test the hypothesis that a single carnivore predator, usually an asteroid species, could play a pivotal role on local species diversity. The wave exposed coast of central Chile was one of those shores that helped generalize the keystone concept. Through an experimental manipulation conducted in the early 80's, Paine and Chilean investigators (Paine et al. 1985) demonstrated that the seastar Heliaster helianthus (Lamarck) was a keystone species that controled the abundance of the competitively dominant intertidal mussel. Few researchers know that the rocky benches where Paine et al. (1985) experiments were conducted are located in Las Cruces, "inside" what later became the marine reserve of ECIM. At the time of Paine et al.'s experiments, fishers had free access to the shore and kept the biomass of the "other" (perhaps the "real") keystone predator in the system, Concholepas concholpeas, at very low levels. Thus, after the profound transformation of the seascape triggered by Concholepas when the ECIM reserve was established (see above), the demonstrated role of Heliaster as a unique keystone predator had to be revised. Clearly the role of Concholepas had been under-estimated and it seemed that at least two predator species could play major roles in this rocky shore. Indeed, further experiments (Navarrete \& Castilla 2003) have shown that Heliaster and Concholepas can play major roles in these communities and their effects are far larger than those of the many other benthic predators that coexist in this system. Or at least that's the level of our understanding so far.

What have we learned for marine management and conservation policies?

Ecological literacy is the ability to understand the natural system that makes life on earth possible; to understand the principles behind the functioning of ecosystems and use those principles for creating sustainable futures (Orr 1992). As noted in the above sections of this paper, information from long-term monitoring programs within and outside of a marine reserve at Las Cruces has greatly enhanced our understanding of unexpected pathways in ecosystem dynamics and the role of humans influencing these processes. This information provides basic building blocks, the necessary ecological literacy, for current and future management and conservation of marine environments. In the specific case of Chile, scientific knowledge generated in Las Cruces reserve triggered a learning process which was eventually institutionalized and converted into a national marine fisheries and management policy. There have been important attempts to summarize this institutionalization of ecological knowledge in Chile (see Castilla et al. 2007b, Castilla \& Gelcich 2008, for different aspects of this process) and it is beyond the scope of this paper to summarize these findings. We will just mention two key points that relate directly to the role of ecological literacy, which stemmed from long-term monitoring programs.

In essence, research from long-term studies ( $>5$ years) in Las Cruces provided information on natural restocking of fishery resources (Castilla \& Durán 1985), rates of resource recovery (Castilla \& Bustamante 1989, Castilla et al. 1998, Castilla et al. 2007b) and multi-scale ecosystem dynamics (Castilla 1999). Similar experiences in the now terminanted marine reserve of Mehuin in southern Chile supported the notion that rapid recovery of over-exploited invertebrate populations was possible, repeatable and occurred even in small sections of the coast (Moreno et al. 1984, Moreno et al. 1986, Moreno 2001). Unfortunately, with termination of this reserve, the opportunity to assess the generality of patterns detected in the ECIM reserve or geographic variation of such patterns can no longer be assessed. It must be noted that ECIM is a very small marine reserve (and so was Mehuin) of just about 500 $\mathrm{m}$ linear coastline and so the dynamics inside are expected to be influenced by the surrounding environment. Nonetheless, even these small MPA's revealed the influence of human activities with sharp and rapid (1-3 years) recovery of invertebrate populations, contrasting sharply with patterns recently reported for marine reserves in Tasmania (Barret et al. 2009). It was precisely this rapid 
recovery that made it possible to demonstrate the value of the reserve as a tool for coastal conservation and fisheries management. As a result, these studies allowed the articulation of links between basic research (i.e., ecological principles) and applied science, thereby building the science foundations needed to support informed decision-making regarding marine sustainable management.

Knowledge from the recovery and the monitoring of Las Cruces and other areas was disseminated to non-scientists, principally groups of artisanal fishers. This knowledge prompted the necessary dialogue between scientists and fishers to establish a co-learning exercise (Gelcich et al. 2005). Fishers and scientists established joint experimental notake areas in order to minimize inaccuracies of the Las Cruces data at broader scales, thereby fostering ecological literacy under the premise that the participation of resource users is important not only in the management of resources, but also in research oriented toward the generation of information and innovations (Edwards-Jones 2001, Gelcich et al. 2006, Gelcich et al. 2008). Finally, research from Las Cruces was used by scientists and other stakeholders (i.e., fishers) in taking proactive positions that promoted infusion of sound science into policy implementation (Castilla \& Gelcich 2008).

The boundaries between science and policy are not fixed; rather, they are routinely renegotiated by various stakeholders in particular contexts and in regards to particular issues (Gray \& Campbell 2009). Thus, a key challenge is to strengthen and expand the constructive role that science has contributed to the management of coastal resources to inform the design and management for marine biodiversity. Long-term ecological monitoring programmes seem a fundamental component for the task, as they provide the necessary baselines to build ecological literacy and in doing so, motivate the necessary dialogue and innovations for adaptations (Folke 2006).

\section{Funding challenges and the need to implement a network of effective no-take marine reserves}

The Chilean Innovation Council for Competitiveness (CNIC) aims to double Chile's Gross Internal Product by 2020 through investing strongly in innovation, knowledge, and human competences (CNIC 2006). It considers that this strategy should be applied mainly to those productive sectors that have the highest potential for development such as mining, agriculture-based food products, special interest tourism and aquaculture (CNIC 2006). Additionally, the CNIC has selected the "environment" as one of five critical crosscutting supporting services to achieve these development goals. In this context, long-term marine ecological monitoring is fundamental to provide Chile with timely information that facilitates increasingly adaptive policies and priority setting. It also identifies changes and trends occurring in marine ecosystems and, as a result, policy makers are better able to make decisions related to development, conservation and sustainability.

In this article we have shown how long term ecological monitoring within and outside a marine reserve at Las Cruces and related research programs provide the necessary benchmarks, knowledge and dialogue to confront marine management and conservation issues under global environmental change scenarios. The examples also illustrate the importance of not only creating, but actually extensively monitoring and effectively maintaining no-take marine reserves along the coast of Chile. Historically, Chilean legislation (Fisheries and Aquaculture Law) has employed marine reserves for the purpose of conserving genetic diversity of economically important biological resources and only recently the ecosystems that support such resources. Such reserves are managed by the Undersecretary of Fisheries. The no-take reserve of Las Cruces is an exception (for others see Fernández \& Castilla 2005), which has been financed privately and with little legal support, for 23 years, by ECIM, of the P. Universidad Católica de Chile. Only five years ago the legislation allowed the creation of protected areas for conservation purposes in Chile, under the name of "Areas Marinas Costeras Protegidas" (AMCP), and in 2005 Las Cruces was officially declared an AMCP. However, this new model of protected areas that emerged in Chile, under the administration of the National Commission for the Environment (CONAMA), is not the one 
we fostered and benefited from the Las Cruces' experience. Instead, the concept of AMCP's in Chile (except for the one in Las Cruces) is one of multiple-uses, which include areas for biodiversity conservation, regulated fisheries, tourism and education, usually within a very large section of coast $(>15 \mathrm{~km}$ coastline). This makes maintenance and monitoring difficult or impossible to achieve. It is important to highlight that AMCP are only one tool for marine conservation and that a broader integrated network for marine conservation in which comparatively large sustainable use Management and Exploitation Areas for Benthic Resources (MEABRs) and smaller no-take marine reserves (such as the one of Las Cruces) and sanctuaries are fundamental elements. Thus, although AMCP might be a step forward, we must unfortunately say that in Chile the need to create no-take marine reserves with efficient monitoring programmes, still remains, despite continuous claims from the scientific community over the past 30 years (Castilla 1976, 1986, Moreno \& Vega 1988, Castilla 1996, 2002).

Funding of long-term monitoring programs remains an important challenge in developing countries such as Chile. Thus there is a need to incorporate ecological literacy as a basic element of Chile's development agenda. One important strategy could be to frame ecological literacy as a building block within Chile's existing innovation and competitiveness strategies. To date, however, the generation of marine long-term monitoring data in Chile (e.g., Duarte et al. 1996, Moreno \& Rubilar 1997, Vásquez et al. 2006, Castilla et al. 2007a) has not been valued and has been dependent on the work of a few key stewards, researchers who have maintained monitoring initiatives, as those presented in this paper, through self-funded, short-term research grants. Thus, a long-term monitoring scheme of linked social-ecological systems in Chile should become a national priority and the only way to achieve the proposed 2020 development target. This scheme should take the form of a network (Vaughan et al. 2001) and must include longterm multi-disciplinary monitoring along the coast, through core variables (e.g., ecology, sociology, oceanography) of social-ecological system change. This network would include a number of cooperative dispersed monitoring initiatives in order to deliver the necessary knowledge to determine baselines from which ecological literacy can be built upon.

\section{SUPPLEMENTARY MATERIAL}

The Spanish version of this article is available as online Supplementary Material at http:// rchn.biologiachile.cl/suppmat/2010/1/ SM_Navarrete_et_al_2010.pdf

\section{ACKNOWLEDGEMENTS}

Collecting data over many years and from disparate components of coastal communities is a monumental task that cannot be achieved by single individuals and certainly this is not an exception. The authors of this contribution have merely summarized the efforts of many friends, colleagues, students, postdocs and research assistants. It would be impossible to list them all here. To all them we are very grateful for their continuous enthusiasm and for making possible the existence of ECIM reserve and its small but productive scientific community. Several granting agencies have made these studies possible. We'll be remised not to mention Fondecyt Regular, Inititation and Postdoctoral grants to the authors of this contribution over the past decades. Yet, many of these long-term monitoring programs would have been literally impossible to maintain without the support the International Development Research Council, Canada, the Andrew Mellon Foundation, and the Fondap Fondecyt 15001-001 grant to the Center for Advanced Studies in Ecology and Biodiversity (CASEB). More recently, the Laboratorio Internacional de Cambio Global (LINCGlobal CSIC-PUC) has supported the continuation and valued the importance of these research programs.

\section{LITERATURE CITED}

BARRETT NS, CD BUXTON \& GJ EDGAR (2009) Changes in invertebrate and macroalgal populations in Tasmanian marine reserves in the decade following protection. Journal of Experimental Marine Biology and Ecology 370: 104-119. 
BOTSFORD LW, JC CASTILLA \& CH PETERSON (1997) The management of fisheries and marine ecosystems. Science 277: 509-515.

BOTSFORD LW, A HASTINGS \& MS GAINES (2001) Dependence of sustainability on the configuration of marine reserves and larval dispersal distance. Ecology Letters 4: 144-150.

BUSTAMANTE RH \& JC CASTILLA (1987) The shellfishery in Chile: An anlysis of 26 years of landings (1960-1985). Biología Pesquera 16: 7997.

BUSTAMANTE RH \& JC CASTILLA (1990) Impact of human exploitation on populations of the intertidal southern bull-kelp Durvillaea antarctica (Phaeophyta, Durvilleales) in central Chile. Biological Conservation 52: 205-220.

CAMUS PA \& M LIMA (1995) El uso de la experimentación en ecología: Supuestos, limitaciones, fuentes de error y su status como herramienta explicativa. Revista Chilena de Historia Natural 68: 19-42.

CARR MH (2000) Marine protected areas: Challenges and opportunities for understanding and conserving coastal marine ecosystems. Environmental Conservation 27: 106-109.

CARR MH \& DC REED (1993) Conceptual issues relevant to marine harvest refuges: Examples from temperate reef fishes. Canadian Journal of Fisheries and Aquatic Sciences 50: 2019-2028.

CASTILLA JC (1976) Chilean marine parks and reserves: Need of establishment, sites and basic criteria. In: First Symposium on Marine Parks and Reserves. Tokyo, Japan.

CASTILLA JC (1986) ¿Sigue existiendo la necesidad de establecer parques y reservas marítimas en Chile? Ambiente y Desarrollo 2: 53-63.

CASTILLA JC (1993) Humans: Capstone strong actors in the past and present coastal ecological play. In: McDonnell MJ \& STA Pickett (eds) Humans as components of ecosystems. The ecology of subtle effects and populated areas: 158-162. Springer Verlag, New York.

CASTILLA JC (1996) La futura red chilena de parques y reservas marinas y los conceptos de conservación, preservación y manejo en la legislación nacional. Revista Chilena de Historia Natural 69: 253-270.

CASTILLA JC (1999) Coastal marine communities: Trends and perspectives from human-exclusion experiments. Trends in Ecology and Evolution 14: $280-283$

CASTILLA JC (2000) Roles of experimental marine ecology in coastal management and conservation. Journal of Experimental Marine Biology and Ecology 250: 3-21.

CASTILLA JC (2002) Los parques marinos en Chile: Conservación/manejo y la relación entre investigación e industria. Ambiente y Desarrollo 18: $137-141$.

CASTILLA JC \& RH BUSTAMANTE (1989) Human exclusion from rocky intertidal of Las Cruces, central Chile: Effects on Durvillaea antarctica (Phaeophyta, Durvilleales). Marine Ecology Progress Series 50: 203-214.

CASTILLA JC, M CAMPO \& RH BUSTAMANTE (2007a) Recovery of Durvillaea antarctica (Durvilleales) inside and outside Las Cruces marine reserve, Chile. Ecological Applications 17: 1511-1522.

CASTILLA JC \& LR DURÁN (1985) Human exclusion from the rocky intertidal zone of central Chile: The effects on Concholepas concholepas (Gastropoda). Oikos 45: 391-399.

CASTILLA JC \& S GELCICH (2008) Management of the loco (Concholepas concholepas) as a driver for self-governance of small-scale benthic fisheries In: Chile. FAO Fisheries Technical Paper, Rome.

CASTILLA JC, S GELCICH \& O DEFEO (2007b) Successes, lessons and projections from experience in marine benthic invertebrate artisanal fisheries in Chile. In: McClanahan T \& JC Castilla (eds) Fisheries management: Progress toward sustainability: 24-42. Blackwell Publishing, Oxford.

CASTILLA JC, P MANRÍQUEZ, J ALVARADO, A ROSSON, C ESPOZ, R SOTO, D OLIVA \& O DEFEO (1998) Artisanal "caletas" as units of production and co-managers of benthic invertebrates in Chile. In: Jamieson GS \& A Campbell (eds) Proceedings of the north pacific symposium on invertebrate stock assessment and management: 407-413. Canadian Special Publication of Fisheries and Aquatic Sciences.

CASTILLA JC \& RT PAINE (1987) Predation and community organization on Eastern Pacific, temperate zone, rocky intertidal shores. Revista Chilena de Historia Natural 60: 131-151.

CNIC (2006) Hacia una estrategia nacional de innovación para la competitividad. Vol. 1. Consejo Nacional de Innovación para la Competitividad. In: GTD Chile (ed) Gobierno de Chile: 189

CORNELIUS C, SA NAVARRETE \& PA MARQUET (2001) Effects of human activity on the structure of coastal marine bird assemblages in central Chile. Conservation Biology 25: 1396-1404.

DAYTON PK, MJ TEGNER, PB EDWARDS \& KL RISER (1998) Sliding baselines, ghosts, and reduced expectations in kelp forest communities. Ecological Applications 8: 309-322.

DUARTE WE, G ASENCIO \& CA MORENO (1996) Long-term changes in population density of Fissurella picta and Fissurella limbata (Gastropoda) in the marine reserve of Mehuín, Chile. Revista Chilena de Historia Natural 69: 4556.

DURÁN LR \& JC CASTILLA (1989) Variation and persistence of the middle rocky intertidal community of central Chile, with and without human harvesting. Marine Biology 103: 555-562.

DYE AH (1998a) Community-level analyses of longterm changes in rocky littoral fauna from South Africa. Marine Ecology-Progress Series 164: 4757.

DYE AH (1998b) Temporal perspectives in environmental surveillance: Examples from the rocky intertidal zone. South African Journal of Science 94: 493-496.

EDWARDS-JONES G (2001) Should we engage in farmer-participatory research in the UK? Outlook on Agriculture 30: 129-136.

ELLIS JC, JM FARIÑA \& JD WITMAN (2006) Nutrient transfer from sea to land: The case of gulls and cormorants in the Gulf of Maine. Journal of Animal Ecology 75: 565-574.

FERNANDEZ M \& JC CASTILLA (2005) Marine conservation in Chile: Historical perspective, lessons, and challenges. Conservation Biology 19: $1752-1762$. 
FOLKE C (2006) Resilience, vulnerability, and adaptation: A cross-cutting theme of the international human dimensions programme on global environmental change. Global Environmental Change 16: 129-136.

GAINES SD \& KD LAFFERTY (1995) Modeling the dynamics of marine species: The importance of incorporating larval dispersal. In: McEdward L (ed) Ecology of marine invertebrate larvae: 389412. CRC Press, New York.

GELCICH S, G EDWARDS-JONES \& MJ KAISER (2005) Importance of attitudinal differences among artisanal fishers with respect to comanagement and conservation of benthic resources. Conservation Biology 19: 865-875.

GELCICH S, G EDWARDS-JONES, MJ KAISER \& JC CASTILLA (2006) Co-management policy can reduce resilience in traditionally managed marine ecosystems. Ecosystems 9: 951-966.

GELCICH S, N GODOY, L PRADO \& JC CASTILLA (2008) Add-on conservation benefits of marine territorial user rights fishery policies in central Chile. Ecological Applications 18: 273-281.

GODOY C \& CA MORENO (1989) Indirect effects of human exclusion from the rocky intertidal in southern Chile: A case of cross-linkage between herbivores. Oikos 54: 101-106.

GRAY N \& L CAMPBELL (2009) Science, policy advocacy, and marine protected areas. Conservation Biology 23: 460-468.

JACKSON JBC, MX KIRBY, WH BERGER, KA BJORNDAL, LW BOTSFORD et al. (2001) Historical overfishing and the recent collapse of coastal ecosystems. Science 293: 629-638.

JAENIKE J (2007) Comment on "Impacts of biodiversity loss on ocean ecosystem services". Science 316: 1.

JARA HF \& CA MORENO (1984) Herbivory and structure in a midlittoral rocky community: A case in southern Chile. Ecology 65: 28-38.

JERARDINO A, JC CASTILLA, JM RAMÍREZ \& N HERMOSILLA (1992) Early coastal subsistence patterns in central Chile: A systematic study on the marine-invertebrate fauna from the site of Curaumilla-1. Latin American Antiquity 3: 43-62.

LEWONTIN R (1969) The meaning of stability. Diversity and stability in ecological systems: 1324. Brookhaven Symposia in Biology. Brookhaven National Laboratory, Brookhaven, New York

LOOT G, M ALDANA \& SA NAVARRETE (2005) Effects of human exclusion on parasitism in intertidal food webs of central Chile. Conservation Biology 19: 203-212.

MARTÍNEZ P \& SA NAVARRETE (2002) Temporal and spatial variation in settlement of the gastropod Concholepas concholepas in natural and artificial substrata. Journal Marine Biological Association UK 82: 257-264

MORENO CA (1984) Crítica a los métodos experimentales en ecología de comunidades. Revista Chilena de Historia Natural 57: 105-106.

MORENO CA (2001) Community patterns generated by human harvesting on Chilean shores: A review. Aquatic Conservation-Marine and Freshwater Ecosystems 11: 19-30.

MORENO CA, KM LUNECKE \& MI LÓPEZ (1986) The response of an intertidal Concholepas concholepas (Gastropoda) population to protection from Man in southern Chile and effects on benthic assemblages. Oikos 46: 359364.

MORENO CA \& PS RUBILAR (1997) Densidad de poblaciones protegidas en reservas marinas: Cambios en el tiempo y eventual efecto de la explotación. Estudios Oceanológicos 16: 41-50.

MORENO CA, JP SUTHERLAND \& HF JARA (1984) Man as a predator in the intertidal zone of southern Chile. Oikos 42: 155-160.

MORENO CA \& R VEGA (1988) Valor científico de las reservas marinas costeras: Un ejemplo de estudio ecológico con poblaciones intermareales de Loxechinus albus (Molina). Informe Unesco Ciencias Mar 47: 124-134.

MURAWSKI S, R METHOT \& G TROMBLE (2007) Biodiversity loss in the ocean: How bad is it? Science 316: 1281-1281.

MYERS RA \& B WORM (2003) Rapid worldwide depletion of predatory fish communities. Nature 423: 280-283.

NAVARRETE SA, B BROITMAN, EA WIETERS, GR FINKE, RM VENEGAS \& A SOTOMAYOR (2002) Recruitment of intertidal invertebrates in the southeast Pacific: Inter-annual variability and the 1997-1998 El Niño. Limnology and Oceanography 47: 791-802.

NAVARRETE SA, BR BROITMAN \& BA MENGE (2008) Interhemispheric comparison of recruitment to rocky intertidal communities: Pattern persistence and scales of variation. Ecology 89: 1308-1322.

NAVARRETE SA \& JC CASTILLA (1990) Resource partitioning between intertidal predatory crabs: Interference and refuge utilization. Journal of Experimental Marine Biology and Ecology 143: 101-129.

NAVARRETE SA \& JC CASTILLA (2003) Experimental determination of predation intensity in an intertidal predator guild: Dominant versus subordinate prey. Oikos 100: 251-262.

NAVARRETE SA, E WIETERS, B BROITMAN \& JC CASTILLA (2005) Scales of benthic-pelagic coupling and the intensity of species interactions: From recruitment limitation to top down control. Proceeding of the National Academy of Sciences USA 102: 18046-18051.

OLIVA D \& JC CASTILLA (1986) The effect of human exclusion on the population structure of key-hole limpets Fissurella crassa and $F$. limbata on the coast of central Chile. P.S.Z.N. Marine Ecology 7: 201-217.

ORR D (1992) Ecological literacy: Education and the transition to a postmodern world. S.U.N.Y Press, New Tork.

PAINE RT (1966) Food web complexity and species diversity. American Naturalist 100: 65-75.

PAINE RT, JC CASTILLA \& J CANCINO (1985) Perturbation and recovery patterns of starfishdominated intertidal assemblages in Chile, New Zealand, and Washington State. American Naturalist 125: 679-691.

PAULY D (1995) Anecdotes and the Shifting Base-Line Syndrome of Fisheries. Trends in Ecology \& Evolution 10: 430-430.

POWER ME, D TILMAN, JA ESTES, BA MENGE, WJ BOND et al. (1996) Challenges in the quest for keystones. BioScience 46: 609-620.

ROUGHGARDEN J, SD GAINES \& H POSSINGHAM (1988) Recruitment dynamics in complex life cycles. Science 241: 1460-1466. 
SCHEFFER M, S CARPENTER, J FOLEY, C FOLKE \& B WALKER (2001) Catastrophic shifts in ecosystems. Nature 413: 591-596.

SHANKS AL, B GRANTHAM \& MH CARR (2003) Propagule dispersal distance and the size and spacing of marine reserves. Ecological Applications 13: s159-s169.

STENSETH NC, A MYSTERUD, G OTTERSEN, J HURRELL, K-S CHAN \& M LIMA ( 2002) Ecological effects of climate fluctuations. Science 297: 1292-1296.

STENSETH NC, G OTTERSEN, J HURRELL, A MYSTERUD, M LIMA, K-S CHAN, NG YOCCOZ \& B ADLANDSVIK (2003) Studying climate effects on ecology through the use of climate indices: The North Atlantic Oscillation, El Niño Southern Oscillation and beyond. Proceedings of the Royal Society of London B 270: 2078-2096.

THORSON GL (1950) Reproductive and larval ecology of marine bottom invertebrates. Biological Reviews of the Cambridge Philosophical Society 25: $1-45$.

UNDERWOOD AJ (2000) Experimental ecology of rocky intertidal habitats: What are we learning? Journal of Experimental Marine Biology and Ecology 250: 51-76.

VÁSQUEZ JA, JMA VEGA \& AH BUSCHMANN (2006)
Long term variability in the structure of kelp communities in northern chile and the 1997-98 ENSO. Journal of Applied Phycology 18: 505-519.

VAUGHAN H, T BRYDGES, A FENECH \& A LUMB (2001) Monitoring long-term ecological changes through the Ecological Monitoring and Assessment Network: Science-based and policy relevant. Environmental Monitoring Assessment 67: 3-28.

WIETERS EA, SD GAINES, SA NAVARRETE, C BLANCHETTE \& BA MENGE (2008) Scales of dispersal and the biogeography of marine predator-prey interactions. American Naturalist 171: 405-417.

WIETERS EA, E SALLES, SM JANUARIO \& SA NAVARRETE (2009) Refuge utilization and preferences between competing intertidal crab species. Journal of Experimental Marine Biology and Ecology 374: 37-44

WORM B, EB BARBIER, N BEAUMONT, JE DUFFY, C FOLKE et al (2006) Impacts of biodiversity loss on ocean ecosystem services. Science 314 : 787-790.

WORM B, EB BARBIER, N BEAUMONT, JE DUFFY, C FOLKE et al. (2007) Biodiversity loss in the ocean: How bad is it? Response. Science 316: 1282-1284. 
